\title{
Production and Physiological Actions of Anandamide in the Vasculature of the Rat Kidney
}

\author{
Dale G. Deutsch, ${ }^{\star}$ Michael S. Goligorsky, ${ }^{\star}$ Patricia C. Schmid, ${ }^{\ddagger}$ Randy J. Krebsbach, ${ }^{\ddagger}$ Harald H.O. Schmid, ${ }^{\ddagger}$ S.K. Das, \\ S.K. Dey, ${ }^{\S}$ G. Arreaza, ${ }^{*}$ Christian Thorup, ${ }^{*}$ George Stefano, $\|$ and Leon C. Moore ${ }^{\star}$ \\ *Department of Biochemistry \& Cell Biology, Department of Medicine, and Department of Physiology \& Biophysics, State University of \\ New York, Stony Brook, New York 11794; ${ }^{\ddagger}$ The Hormel Institute, University of Minnesota, Austin, Minnesota 55912; ${ }^{\S}$ Department of \\ Physiology, University of Kansas Medical Center, Ralph L. Smith Research Center, Kansas City, Kansas 66160-7338; and the \\ "Neuroscience Institute, State University of New York, Old Westbury, New York 11586
}

\begin{abstract}
The endogenous cannabinoid receptor agonist anandamide is present in central and peripheral tissues. As the kidney contains both the amidase that degrades anandamide and transcripts for anandamide receptors, we characterized the molecular components of the anandamide signaling system and the vascular effects of exogenous anandamide in the kidney. We show that anandamide is present in kidney homogenates, cultured renal endothelial cells (EC), and mesangial cells; these cells also contain anandamide amidase. Reverse-transcriptase PCR shows that EC contain transcripts for cannabinoid type 1 (CB1) receptors, while mesangial cells have mRNA for both $\mathrm{CB} 1$ and $\mathrm{CB} 2$ receptors. EC exhibit specific, high-affinity binding of anandamide $\left(K_{\mathrm{d}}=27.4 \mathrm{nM}\right)$. Anandamide $(1 \mu \mathrm{M})$ vasodilates juxtamedullary afferent arterioles perfused in vitro; the vasodilation can be blocked by nitric oxide (NO) synthase inhibition with L-NAME (0.1 mM) or CB1 receptor antagonism with SR 141716A $(1 \mu \mathrm{M})$, but not by indomethacin $(10 \mu \mathrm{M})$. Anandamide (10 $\mathrm{nM})$ stimulates CB1-receptor-mediated NO release from perfused renal arterial segments; a similar effect was seen in EC. Finally, anandamide $(1 \mu \mathrm{M})$ produces a NO-mediated inhibition of KCl-stimulated $\left[{ }^{3} \mathrm{H}\right]$ norepinephrine release from sympathetic nerves on isolated renal arterial segments. Hence, an anandamide signaling system is present in the kidney, where it exerts significant vasorelaxant and neuromodulatory effects. (J. Clin. Invest. 1997. 100: 1538-1546.) Key words: cannabinoids • endothelial cells • afferent $\bullet$ anandamide amidase $\bullet$ nitric oxide
\end{abstract}

\section{Introduction}

Cannabis has been used as an herbal preparation for millennia for both its central and peripheral effects (1). In the last decade, cannabinoid receptors (CB1 and $\mathrm{CB} 2$ ) that bind the active component in marijuana $\left(\Delta^{9}\right.$-tetrahydrocannabinol) have been

Address correspondence to Dale G. Deutsch, Ph.D., Department of Biochemistry \& Cell Biology, State University of New York, Stony Brook, NY 11794-5215. Phone: 516-632-8595; FAX: 516-632-8575.

Received for publication 7 March 1997 and accepted in revised form 22 July 1997.

J. Clin. Invest.

(C) The American Society for Clinical Investigation, Inc. 0021-9738/97/09/1538/09 \$2.00

Volume 100, Number 6, September 1997, 1538-1546

http://www.jci.org described in the brain and peripheral tissues $(2,3)$. Anandamide ( $N$-arachidonoylethanolamine), an endogenous cannabinoid receptor agonist, was isolated from porcine brain (4) and confirmed to be present in brains of other mammals (5-7). Anandamide has also been shown to occur in peripheral tissues such as the uterus (8), testis (9), spleen, skin, and heart (7).

In neural tissues, activation of the CB1 receptor is known to inhibit adenylate cyclase via pertussis toxin-sensitive G-protein (10), inhibit agonist-stimulated formation of inositol phosphates (11), inhibit N-type calcium channels via a G-proteinmediated mechanism independent of cAMP (12), and to inhibit gap junctional conductance (13). Exogenous anandamide has also been shown to act as a vasodilator in cerebral arterioles (14) and to modulate neurotransmitter release $(15,16)$.

In view of the wide-ranging effects of anandamide, as well as previous studies demonstrating that the kidney contains the enzyme that degrades anandamide (17) and transcripts for the CB1 receptor (18), we performed molecular and physiological studies to determine if a functional cannabinoid signaling system is present in the renal vasculature. Specifically, we confirm that transcripts for the cannabinoid receptors and the enzyme for the breakdown of anandamide are present in cultured renal endothelial and mesangial cells and in kidney homogenates. Furthermore, we demonstrate that anandamide and its putative precursor, $N$-arachidonoyl phosphatidyl ethanolamine, is present in the kidney and in cultured endothelial and mesangial cells, and that anandamide binds with high affinity to $\mathrm{CB} 1$ receptors on endothelial cells. We also demonstrate that exogenous anandamide vasodilates juxtamedullary afferent arterioles, and inhibits norepinephrine release from renal sympathetic nerves. Finally, we show that anandamide, via CB1 receptors, stimulates renal endothelial cells to release nitric oxide (NO), which is an important mediator of the hemodynamic and neurological actions of anandamide in the renal vasculature.

\section{Methods}

Analysis of anandamide and its precursors. Long-chain $\mathrm{N}$-acylethanolamines (NAEs), ${ }^{1}$ including anandamide, were isolated from the lipid extracts (19) of rat kidney and pelleted cultured renal microvascular endothelial cells and glomerular mesangial cells. Mesangial cells were primary cultures between passages 5-8 (20), and the endothelial

1. Abbreviations used in this paper: $\mathrm{CB}$, cannabinoid; JM, juxtamedullary; KRB, Krebs-Ringer-bicarbonate; L-NAME, $N$-nitro-L-arginine methyl ester; mAA, midafferent arteriole; NAE, $N$-acylethanolamine; NAPE, $N$-acylphosphatidylethanolamine; NE, norepinephrine; NO, nitric oxide; RT PCR, reverse transcription PCR; tBDMS, tert-butyldimethyl chlorosilyl/imidazole. 
cells were derived from renal resistance arteries and were immortalized via SV-40 transfection (21). A mixture of d4 NAEs, namely, $N-16: 0,17: 0,18: 0,18: 1 \mathrm{n}-9,18: 2 \mathrm{n}-6$, and 20:4n-6 [1,1,2,2,- $\left.{ }^{2} \mathrm{H}_{4}\right]$ ethanolamines $(1 \mu \mathrm{g}$ each) plus $3 \mu \mathrm{g}$ of a NAPE internal standard ( $N$-heptadecanoyl-1,2-diheptadecanoyl PE) were added before extraction, and the lipids were fractionated by TLC on layers of silica gel $\mathrm{H}$ using chloroform:methanol:concentrated ammonium hydroxide (90:10:1, by vol) as developing solvent. NAE and NAPE standards were spotted at the margin. Plates were sprayed with $2^{\prime}, 7^{\prime}$-dichlorofluorescein $(0.1 \%$ in ethanol $)$ and viewed under UV light. Bands corresponding to NAE and NAPE were scraped off and eluted with chloroform: methanol:water (30:50:20, by vol). Chloroform and water were added to bring the final ratio of chloroform:methanol:water to 8:4:3 (by vol), and the lower layer was removed and brought to dryness under $\mathrm{N}_{2}$.

The NAE fractions were derivatized with tert-butyldimethyl chlorosilyl/imidazole ( $t$ BDMS) reagent as described (5), and the NAE$t$ BDMS derivatives were extracted into $50 \mu l$ of hexane for gas chromatography-mass spectrometry analysis. The NAPE fractions were hydrolyzed with phospholipase D (Streptomyces chromofuscus) as described (22) in the presence of deuterated NAEs to serve as internal standards. NAEs were isolated by TLC on silica gel $\mathrm{H}$, using hexane:diethylether:acetone:glacial acetic acid (40:20:20:1, by vol) as developing solvent, and derivatized.

Analysis of NAE-tBDMS derivatives was done essentially as described (5) by measuring the M-57 ion in the selected ion monitoring mode. Endogenous NAEs were quantified by comparing their M-57 ions to those of the d4 NAEs. Their levels were normalized to total lipid phosphorus of each sample. The 17:0 NAE derived from the NAPE internal standard was used to correct for losses during purification, degradation, and derivatization.

Analysis of $C B 1$ and $C B 2$ receptor $m R N A$ s. Reverse transcription polymerase chain reaction (RT-PCR) was used to detect mRNAs for the known cannabinoid receptors, CB1 and CB2, in kidney mesangial and endothelial cells $(20,21)$. The following primers, based upon the sequences of Matsuda et al. (2) and Munro et al. (3), were used for RT-PCR: 5'-GGAGAACATCCAGTGTGGGG-3' (sense) and 5'-CATTGGGGCTGTCTTTACGG-3' (antisense) for the CB1 receptor, and 5'-CCTGTTGAAGATCGGCAGCG-3' (sense) and 5'-GGTAGGAGATCAACGCCGAG-3' (antisense) for the CB2 receptor, as previously reported by Das et al. (23). The internal oligonucleotides 5'-GGTTCTGGAGAACCTACTGG-3' and 5'-TGGGCAGCCTGCTGCTGACT-3' were used for Southern blot hybridization of the amplified products for the CB1 and CB2 receptors, respectively. The primers for the $\beta$-actin RT/PCR and the internal primer for Southern hybridization were as described (23).

Total RNA was isolated from endothelial and mesangial cells and reverse-transcribed using specific antisense primers. One-third of RT products was PCR-amplified using the sense and antisense primers. PCR cycle parameters were as follows: $94^{\circ} \mathrm{C}$ for $4 \mathrm{~min}, 55^{\circ} \mathrm{C}$ for 1.5 min, and $72^{\circ} \mathrm{C}$ for $2.5 \mathrm{~min}$ for the first cycle, followed by 35 cycles of $1-, 1.5-$, and 2.5-min duration. PCR products were subjected to electrophoretic separation on $1.5 \%$ agarose gels, and were analyzed by Southern blot hybridization as described by Paria et al. (24). Experimental samples and negative controls were run simultaneously.

Measurement of anandamide amidase and synthase. Anandamide amidase (enzyme commission 3.5.1.4; arachidonoyl ethanolamide amidohydrolase) activity was measured in homogenates of endothelial and mesangial cells using the substrate $\mathrm{N}$-arachidonoyl ethanolamine (ethanolamine-1,2-14C) (Dupont-NEN, Boston, MA) as recently described (25). In brief, endothelial and mesangial cultured cells were harvested and washed once in PBS, $\mathrm{pH}$ 7.5; cell pellets were lysed and homogenized in $20 \mathrm{mM}$ Tris, $\mathrm{pH} 9.0,1 \mathrm{mM}$ EDTA with protease inhibitor cocktail $(1 \mathrm{mg} / \mathrm{ml}$ pepstatin $\mathrm{A}, 0.5 \mathrm{mg} / \mathrm{ml} \mathrm{leu-}$ peptin, $1 \mathrm{mg} / \mathrm{ml}$ aprotinin, $10 \mathrm{mg} / \mathrm{ml}$ benzamidine). $60 \mu \mathrm{g}$ of total protein from homogenates were incubated in $0.1 \mathrm{M}$ Tris, $\mathrm{pH} 8.0,2.5 \mathrm{mg} /$ $\mathrm{ml} \mathrm{BSA}$, and $30 \mathrm{mM}\left[{ }^{14} \mathrm{C}\right]$ anandamide (Dupont-NEN) for $30 \mathrm{~min}$ at $37^{\circ} \mathrm{C}$ in the absence or presence of $1 \mathrm{mM}$ palmitoyl sulfonyl fluoride (negative control) in a final volume of $200 \mu$ l. After incubation sam- ples were extracted with one volume of methanol:chloroform (1:1) and centrifuged, incubations were conducted without protein to account for non-specific hydrolysis of the substrate. The amount of radio-labeled anandamide hydrolyzed was determined by liquid scintillation counting of $200 \mu \mathrm{l}$ of the aqueous layer.

Anandamide synthase activity was measured in homogenates of endothelial and mesangial cells in a reaction mixture consisting of 10 $\mathrm{mM}$ ethanolamine hydrochloride, $20 \mu \mathrm{M}\left[{ }^{14} \mathrm{C}\right]$ arachidonic acid $(1$ $\mu \mathrm{Ci} / \mathrm{ml}, 55 \mathrm{mCi} / \mathrm{mmol}$ ), and $20 \mathrm{mM}$ Tris $\mathrm{HCl}, \mathrm{pH} 9.0$, in a total volume of $100 \mu \mathrm{l}$. The reaction was carried out for $60 \mathrm{~min}$ at $37^{\circ} \mathrm{C}$, extracted with $250 \mu \mathrm{l}$ of chloroform:methanol (2:1), and centrifuged. $200 \mu \mathrm{l}$ of the organic phase was transferred to a clean tube and dried under nitrogen. The residue was redissolved in $20 \mu \mathrm{l}$ of chloroform: methanol, spotted on a TLC plate, and developed as described previously (25). Plates were analyzed on a phosphorimager (Molecular Dynamics Inc., Sunnyvale, CA). To quantify the amount of anandamide produced, the bands comigrating with anandamide standards were quantified against a standard curve of known amounts of $\left[{ }^{14} \mathrm{C}\right]$ anandamide.

$\left[{ }^{3} H\right]$ Anandamide binding in renal endothelial cells. The rat microvascular endothelial cells $\left(\sim 10^{6}\right)$ were homogenized in $50 \mathrm{vol}$ of $0.32 \mathrm{M}$ sucrose, $\mathrm{pH} 7.4$, at $4^{\circ} \mathrm{C}$, by the use of a polytron $(30 \mathrm{~s}$, setting no. 5; Brinkman Instruments, Inc., Westbury, NY). The crude homogenate was centrifuged at $900 \mathrm{~g}$ for $10 \mathrm{~min}$ at $4^{\circ} \mathrm{C}$, and the supernatant was preserved on ice. The whitish crude pellet was resuspended by homogenization (15 s, setting no. 5) in 30 vol of $0.32 \mathrm{M}$ sucrose/Tris- $\mathrm{HCl}$ buffer, $\mathrm{pH}$ 7.4, and centrifuged at $900 \mathrm{~g}$ for $10 \mathrm{~min}$. The extraction procedure was repeated one more time, and the combined supernatants were centrifuged at $900 \mathrm{~g}$ for $10 \mathrm{~min}$. The resulting supernatants $\left(\mathrm{S} 1^{\prime}\right)$ were used immediately. Just before the binding experiment, the $\mathrm{S} 1^{\prime}$ supernatant was centrifuged at $30,000 \mathrm{~g}$ for $15 \mathrm{~min}$, and the resulting pellet (P2) was washed once by centrifugation in 50 vol of the sucrose/Tris- $\mathrm{HCl}$. The $\mathrm{P} 2$ pellet was then resuspended with a Dounce hand-held homogenizer (10 strokes) in $100 \mathrm{vol}$ of buffer. Binding analysis was then performed on the cell membrane suspensions in the presence of $1 \mathrm{mM}$ PMSF.

For displacement analysis, aliquots of membrane suspensions from the cells were incubated with nonradioactive compounds at five concentrations for $10 \mathrm{~min}$ at $22^{\circ} \mathrm{C}$, and then with $\left[{ }^{3} \mathrm{H}\right]$ anandamide for $60 \mathrm{~min}$ at $4^{\circ} \mathrm{C}$. $100 \%$ binding is defined as bound $\left[{ }^{3} \mathrm{H}\right]$ anandamide in the presence of $10 \mu \mathrm{M}$ anandamide, which was used to account for nonspecific binding. $K_{\mathrm{i}}$ is defined as the concentration of drug that elicits half-maximal inhibition of specific binding. The mean $\pm \operatorname{SE}(n=$ 3 , for three experiments analyzed in triplicate) is given. The displacement analysis data indicate the potency of various ligands in displacing $\left[{ }^{3} \mathrm{H}\right]$ anandamide (34 Ci/mmole, New England Nuclear, Boston, MA).

Vascular effects of anandamide in juxtamedulary afferent arterioles. These experiments used the in vitro juxtamedullary (JM) nephron preparation $(26,27)$ to characterize the renal vascular actions of exogenous anadamide. In brief, male Sprague-Dawley rats (200-250 g) were anesthetized with $110 \mathrm{mg} / \mathrm{kg}$ Inactin (Research Biochemicals, Inc., Natick, MA). Left kidneys were cleared via an aortic catheter, removed, and dissected to expose the perihilar cortex, a region where the preglomerular vasculature of JM nephrons is visible. Major arteries supplying the rest of the kidney were ligated. During dissection, the kidneys were perfused with a gassed Krebs-Ringer-bicarbonate (KRB) solution containing 5\% albumin. During measurements, the kidneys were perfused with a blood solution prepared from donor rat blood. The red blood cells were separated, washed, and resuspended ( $~ 30 \% \mathrm{Hct}$ ) in KRB-6\% albumin solution. The preparation was superfused with warmed $\left(37^{\circ} \mathrm{C}\right) \mathrm{KRB}$ solution with $1 \%$ albumin. In this study, all drugs were applied abluminally via the superfusate. The responses of JM midafferent arteriole (mAA) segments were quantified as the change in lumen diameter via videomicroscopy as previously described (27). Results were subjected to one- or two-way ANOVA on repeated measures and Student-Newman-Kuels or Dunnett's multiple comparison tests using SigmaStat software (Jandel Scientific, San Raphael, CA). 
Measurement of anadamide-stimulated NO release. The effect of anandamide on NO release was measured in cultured renal endothelial cells and in renal arterial segments perfused in vitro. Endothelial cells were incubated in $2 \mathrm{ml}$ of Krebs-Henseleit buffer containing (in $\mathrm{mM}) 120 \mathrm{NaCl}, 4.6 \mathrm{KCl}, 1.5 \mathrm{CaCl}_{2}, 0.5 \mathrm{MgCl}_{2}, 1.5 \mathrm{NaH}_{2} \mathrm{PO}_{4}, 0.7$ $\mathrm{Na}_{2} \mathrm{HPO}_{4}, 10$ Hepes, and 10 glucose, $\mathrm{pH}$ 7.4. NO release was monitored with an NO-selective microprobe (Inter Medical Co., Nagoya, Japan). The working electrode ( $25-\mu \mathrm{m}$ tip diameter) made of Pt/Ir alloy was coated with a film containing $\mathrm{KCl}$, an $\mathrm{NO}$-selective nitrocellulose resin (pyroxyline lacquer), and a gas-permeable silicon membrane. The NO sensor was placed 3-5 $\mu \mathrm{m}$ above the cell surface. Electrode calibration and data collection and analysis were as previously described (21).

To measure anandamide-stimulated NO release from intact renal vessels, segments of renal arteries (secondary renal artery branches or primary arcuate) were harvested during dissection for JM arteriole perfusion. The artery segments (300-400 $\mu \mathrm{m}$ diameter, 2-3 mm long) were then cannulated with a double-lumen glass perfusion pipette to permit measurement of intravascular pressure while perfusing with protein-free KRB solution. The distal end of the segment was cannulated with a single lumen glass collection pipette fitted with an adjustable flow resistor. As this resistance was fixed during measurements, and because the hydraulic resistance of the vessel segment is very small in comparison to the resistances of the cannulae, perfusate flow was essentially constant during measurements. NO in the effluent from the artery segment was detected with a porphyrin-electroplated, nafion-coated, NO-sensitive carbon-fiber electrode (30- $\mu \mathrm{m}$ OD mounted in a $700-\mu \mathrm{m}$ OD fused-quartz capillary) and a computerbased electrochemical analysis system (EMS-100; Bio-Logic Science Instruments, Grenoble, France). The electrode was placed inside the collection cannula within $\sim 1 \mathrm{~mm}$ of the tip. The $\mathrm{Ag}: \mathrm{AgCl}$ reference and the silver working electrodes were placed in a heated $\left(37^{\circ} \mathrm{C}\right)$ bath containing KRB solution. Electrode calibration used freshly prepared NO-saturated KRB solution. The NO measurements were made using differential-pulse amperometry $(0.67 \mathrm{~V}$ holding potential, $0.1 \mathrm{~V}$ pulse), with sampling at $10 \mathrm{~Hz}$ followed by a 20 -sample averaging. The resultant 2-s mean values were recorded for analysis. Drugs and chemicals were applied to the lumen of the vessel, and all measurements were made at a luminal pressure of $100 \mathrm{mmHg}$.

Analysis of norepinephrine (NE) release. The effects of anandamide on NE release from rat renal sympathetic nerves was assessed in arterial trees dissected from eight kidneys. The trees consisted of the renal artery, primary and secondary branches, and some large arcuate vessels. The arterial trees were incubated (one tree per chamber) at $24^{\circ} \mathrm{C}$ for $30 \mathrm{~min}$ in $1 \mathrm{ml}$ of Krebs containing $0.1 \%$ ascorbic acid and $\left[{ }^{3} \mathrm{H}\right] \mathrm{NE}\left(0.6 \times 10^{6} \mathrm{dpm}\right.$; specific activity, $\left.31.3 \mathrm{Ci} / \mathrm{mmol}\right)(\mathrm{New}$ England Nuclear) with constant shaking. After being incubated, the arterial tissue (average wet wt $20 \mu \mathrm{g}$ ) was washed twice in $2 \mathrm{ml}$ of Krebs, and then each was transferred to a Plexiglas perfusion chamber containing $2 \mathrm{ml}$ of saline (28). An average of $1950 \mathrm{CPM}$ were present in the vessel segments at the start of the superfusion. A four-channel peristaltic pump (Rainin Instrument Co., Inc., Woburn, MA) maintained the flow rate $(0.2 \mathrm{ml} / \mathrm{min})$ into an opening at the bottom of the chamber. Drugs and chemicals were added to the perfusion solution. The superfusate was collected from an outflow opening with one superfusate fraction $(1 \mathrm{ml})$ collected every $5 \mathrm{~min}$. Vessels were first superfused for $20 \mathrm{~min}$. Then, for the next $15 \mathrm{~min}$ they were superfused with saline containing $50 \mathrm{mM} \mathrm{KCl}$ alone (control) or together with drug. Finally, the artery segments were again perfused with saline for the remainder of the experiment. Radioactivity of the collected superfusate was determined by liquid scintillation counting (28). The values obtained represent the percentage of the total radioactivity in the tissue released during the 5 -min period ending at the time indicated. Each value is the average of two separate experiments, and the variation is $<1.1 \%$ for all values. The ${ }^{3} \mathrm{H}$-labeled substance released was then analyzed with TLC to insure that the material was NE. The results showed that $87 \%$ of the released radioactivity was NE.

\section{Results}

Anandamide levels and metabolism in the rat kidney. As shown in Table I, rat kidney contains both NAPEs and NAEs in a ratio of $\sim 10: 1$. Anandamide amounts to $4.4 \%$ of total NAEs $(0.29 \pm 0.13 \mathrm{pmol} / \mu \mathrm{mol}$ lipid $\mathrm{P} ; 2.79 \pm 1.11 \mathrm{ng} / \mathrm{g}$ wet wt $)$, and the corresponding $20: 4 \mathrm{~N}$-acyl groups in NAPE are $11.2 \%$ of the amide-linked fatty acids. In contrast, cultured mesangial and endothelial cells contain approximately equal amounts of NAEs and NAPEs containing much smaller percentages $(<1 \%)$ of $\mathrm{N}$-arachidonoyl groups. Because NAE levels in these cells are much higher than in kidney homogenate, however, total amounts of anandamide are approximately the same $(0.29$ $0.34 \mathrm{pmol} / \mu \mathrm{mol} \mathrm{P})$. Because rat kidney contains a phospholipase D catalyzing the hydrolysis of NAPE to NAE and phosphatidic acid (29), it is possible that anandamide is produced by this mechanism.

Both the mesangial cells and EC contained anandamide amidase activity, $56 \pm 2$ and $19 \pm 2$ nmol anandamide hydrolyzed per hour per mg protein, respectively (Table II). This value is somewhat higher than the NAE amidase activity (for 18:1 NAE) reported previously for rat kidney homogenate (29). For comparison, the activity of the amidase in brain homogenate at the same anandamide substrate concentration, is $\sim 86 \pm 7 \mathrm{nmol} / \mathrm{h} / \mathrm{mg}$. The mesangial cells and EC also exhibited

Table I. Amounts and Composition of Endogenous NAEs and NAPEs from Rat Kidney, Mesangial, and Endothelial Cells

\begin{tabular}{|c|c|c|c|c|}
\hline & NAE & $\%$ & $N$-acyl of NAPE & $\%$ \\
\hline & $\mathrm{pmol} / \mu \mathrm{mol} P$ & & $\mathrm{pmol} / \mu \mathrm{mol} \mathrm{P}$ & \\
\hline \multicolumn{5}{|l|}{ Kidney** } \\
\hline $16: 0$ & $2.53 \pm 0.92$ & 38.3 & 28.16 & 40.6 \\
\hline 18:0 & $1.89 \pm 0.21$ & 28.6 & 8.80 & 12.7 \\
\hline $18: 1 n-7$ & $0.99 \pm 0.12$ & 15.0 & 6.47 & 9.3 \\
\hline $18: 1 n-9$ & $0.47 \pm 0.55$ & 7.1 & 6.04 & 8.7 \\
\hline $18: 2 n-6$ & $0.43 \pm 0.17$ & 6.5 & 12.04 & 17.4 \\
\hline $20: 4 n-6$ & $0.29 \pm 0.13$ & 4.4 & 7.77 & 11.2 \\
\hline Total & $6.60 \pm 0.75^{\llbracket}$ & & $69.28 * *$ & \\
\hline \multicolumn{5}{|c|}{ Mesangial cells ${ }^{\S}$} \\
\hline $16: 0$ & 14.87 & 14.0 & 51.32 & 43.0 \\
\hline 18:0 & 15.76 & 14.8 & 33.11 & 27.7 \\
\hline $18: 1 n-7$ & 2.62 & 2.5 & 10.37 & 8.7 \\
\hline $18: 1 n-9$ & 71.98 & 67.7 & 22.49 & 18.8 \\
\hline $18: 2 n-6$ & 0.73 & 0.7 & 1.27 & 1.1 \\
\hline $20: 4 n-6$ & 0.34 & 0.3 & 0.85 & 0.7 \\
\hline Total & 106.3 & & 119.41 & \\
\hline \multicolumn{5}{|c|}{ Endothelial cells" } \\
\hline $16: 0$ & 8.47 & 12.2 & 24.43 & 39.7 \\
\hline 18:0 & 6.46 & 9.3 & 12.96 & 21.1 \\
\hline $18: 1 n-7$ & 2.73 & 3.9 & 5.88 & 9.6 \\
\hline $18: 1 n-9$ & 50.66 & 73.3 & 12.94 & 21.0 \\
\hline $18: 2 n-6$ & 0.52 & 0.8 & 4.72 & 7.7 \\
\hline $20: 4 n-6$ & 0.31 & 0.4 & 0.63 & 1.0 \\
\hline Total & 69.15 & & 61.56 & \\
\hline
\end{tabular}

*Data for kidney NAE are mean \pm SD of independent analyses of three kidneys; "Data for kidney NAPE are the average of independent analyses of two kidneys; ${ }^{\S}$ One analysis; "Average of two independent analyses; ${ }^{9} 58.98 \pm 7.04 \mathrm{ng} / \mathrm{g}$ tissue; and $* * 610.1 \mathrm{ng} / \mathrm{g}$ tissue. 
Table II. Assay for Anandamide Amidase and Anandamide Synthase in Rat Kidney, Mesangial, and Endothelial Cells in Culture

\begin{tabular}{lcc}
\hline & Amidase & Synthase \\
\hline & $n m o l / h / m g$ & $p m o l / h / m g$ \\
Mesangial cells & $56 \pm 2$ & $290 \pm 59$ \\
Endothelial cells & $19 \pm 2$ & $298 \pm 72$ \\
Brain homogenate & $80 \pm 14$ & $746 \pm 87$ \\
\hline
\end{tabular}

Data are the mean \pm SD $(n=6$ from triplicate analyses of two independent tissue samples).

synthase activity $(290 \pm 59 \mathrm{pmol} / \mathrm{h} / \mathrm{mg}$ and $298 \pm 72 \mathrm{pmol} / \mathrm{h} / \mathrm{mg}$, respectively). This activity was also less than that observed in the brain, $745 \pm 11 \mathrm{pmol} / \mathrm{h} / \mathrm{mg}$, (Table II). Because the amidase inhibitor methyl arachidonyl fluorophosphate also inhibited synthesis (data not shown), it is likely that both hydrolytic and biosynthetic activities were catalyzed by the same enzyme, as has been shown for other amidases $(30,31)$.

Anandamide binding and cannabinoid receptors. As seen in Fig. 1, Southern analysis of the RT/PCR-amplified products indicates that CB1 mRNA was present in rat mesangial and endothelial cells, as well as in the mouse brain (positive control). RT/PCR products of CB2 were only found in the mesangial cells and spleen (positive control), but not in the endothelial cells. Accordingly, mesangial cells have messages for both the brain type receptor (CB1) and the spleen type receptor (CB2), while endothelial cells only have CB1 receptor mRNA.

Membrane homogenates of rat renal microvascular endothelial cells contained anandamide binding sites (Fig. 2, Table III). Scatchard analysis showed a single, relatively high-affinity binding site with $K_{\mathrm{d}}$ of $27.4 \mathrm{nM}$ and $\mathrm{B}_{\max }$ of $623.3 \mathrm{fmol} / \mathrm{mg}$ membrane protein (Fig. 2). Nonspecific binding increased lin-

A

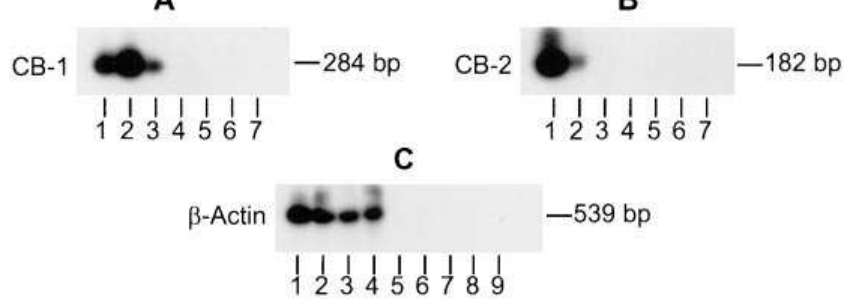

Figure 1. Analysis of $\mathrm{CB} 1$ and $\mathrm{CB} 2$ transcripts in rat renal mesangial and endothelial cultured cells. $(A)$ Southern blot analysis of RT/PCRamplified products of CB1 (284 bp). The conditions for the analysis are described in Methods. Lane 1, mouse brain; lane 2, mesangial cells; lane 3, endothelial cells; lanes 4-6; mouse brain, and mesangial cells, endothelial cells without the RT reaction, respectively; and lane 7, the primer control. (B) Southern blot analysis of RT/PCR-amplified products of CB2 (182 bp). Lane 1, mouse spleen; lane 2, mesangial cells; lane 3, endothelial cells; lanes 4-6, mouse spleen, mesangial cells, and endothelial cells without the RT reaction, respectively; and lane 7 the primer control. $(C)$ Southern blot analysis of RT/PCRamplified products of $\beta$-actin (539 bp). Lane 1, mouse brain; lane 2, mouse spleen; lane 3, mesangial cells; lane 4, endothelial cells; lanes $5-8$, mouse brain, mouse spleen, mesangial cells, and endothelial cells without the RT reaction, respectively; and lane 9, the primer control.

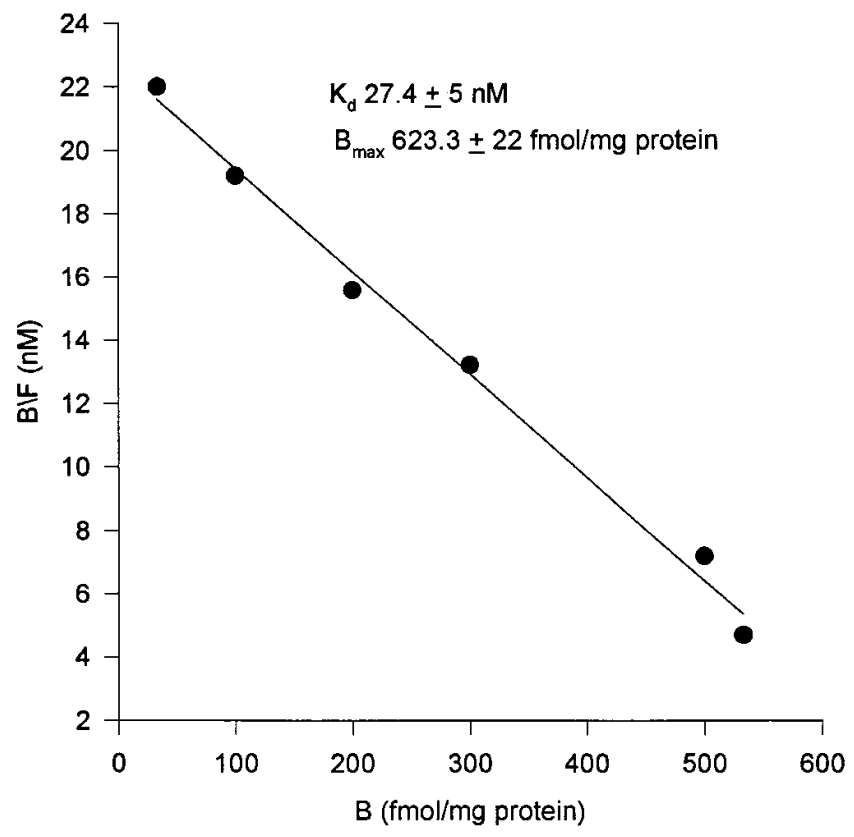

Figure 2. Specific anandamide binding to cultured renal microvascular endothelial cells. Representative Scatchard plot for $\left[{ }^{3} \mathrm{H}\right]$ anandamide binding to cultured renal microvascular endothelial cells. Mean $\mathrm{B}_{\max }$ and $K_{\mathrm{d}}$ values $\pm \mathrm{SE}$ were obtained from three separate experiments.

early with respect to the concentration of the binding ligand (not shown). Furthermore, a variety of diverse signal molecules was found to be ineffective in displacing specifically bound $\left[{ }^{3} \mathrm{H}\right]$ anandamide (Table III). This radioligand, however, can be displaced by the agonists CP 55940 and WIN 55,212-2, and by the antagonist SR 141716A (32) (Table III).

Anandamide-mediated vasorelaxation. Fig. $3 A$ illustrates the effects on JM mAA segments 5-10 min after exposure of 0.1-10 $\mu \mathrm{M}$ anandamide at 60,100 , and $140 \mathrm{mmHg}$ perfusion pressure. The dose-response to anandamide was significantly

Table III. Comparison of Various Signal Molecules for the Displacement of $\left[{ }^{3} \mathrm{H}\right]$ Anandamide in Cultured Renal Microvascular Endothelial Cells

\begin{tabular}{lc}
\hline \multicolumn{1}{c}{ Ligand } & $\mathrm{K}_{\mathrm{i}} \mathrm{nM}$ \\
\hline Anandamide & $29.5 \pm 3.8$ \\
CP 55940 & $28.1 \pm 3.3$ \\
WIN 55,212-2 & $41.6 \pm 5.2$ \\
SR 141716A & $31.5 \pm 4.2$ \\
DPDPE & $>1000$ \\
DAGO & $>1000$ \\
Dopamine & $>1000$ \\
Morphine & $>1000$ \\
Norepinephrine & $>1000$ \\
GABA & $>1000$ \\
Acetylcholine & $>1000$ \\
Glutamate & $>1000$
\end{tabular}

DPDPE, (D-Pen ${ }^{2}$, D-Pen ${ }^{5}$-enkephalin; DAGO, (D-Ala ${ }^{2}, \mathrm{MePhe}^{4}$, Gly $\left.[\mathrm{ol}]^{5}\right)$-enkephalin. Data are the mean \pm SE of three separate experiments with each analyzed in triplicate. 

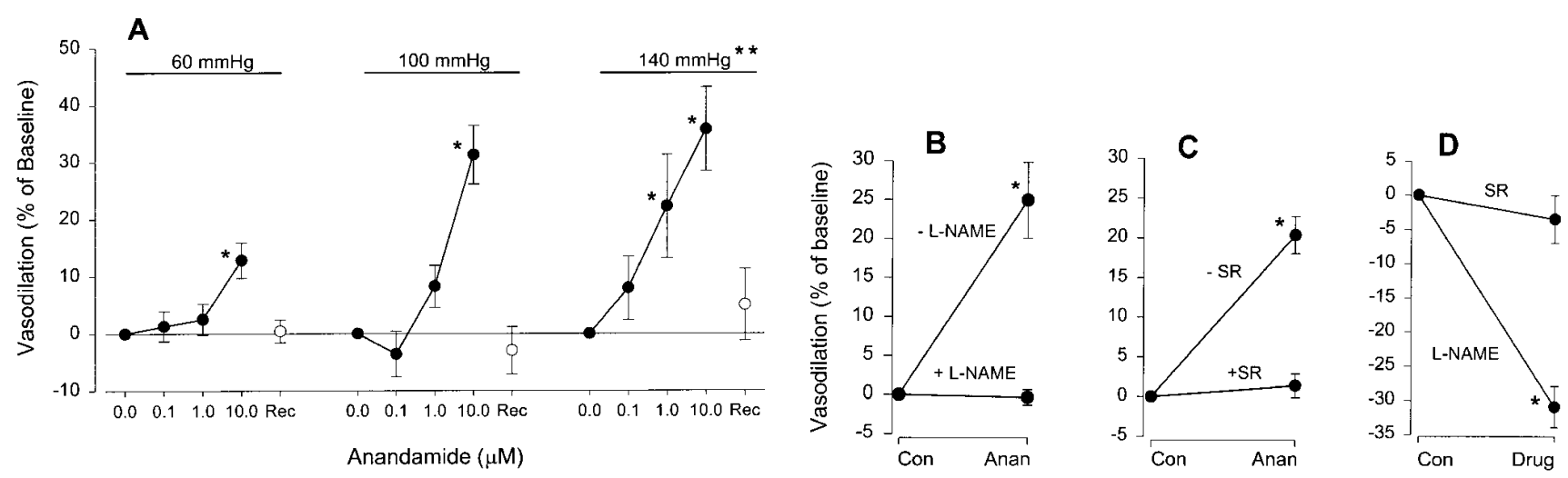

Figure 3. (A) Dose responses to abluminal application of anandamide in juxtamedullary midafferent arteriole segment perfused with blood in vitro at various levels of perfusion pressure. Results are presented as percent change of baseline (zero concentration) lumen diameter at each level of perfusion pressure. Values are mean \pm SEM. *Mean value greater than corresponding baseline, $P<0.05$, repeated measures ANOVA. **The dose responses were significantly influenced by the level of perfusion pressure (two-way repeated measures ANOVA). (B) Effect of L-NAME $(0.1 \mathrm{mM})$ on the vasodilatory response in midafferent arteriolar segments to anandamide $(10 \mu \mathrm{M})$. $*$ Paired responses are different $(P<0.001$, repeated measures ANOVA; $n=9 \mathrm{mAA}$ segments from three kidneys). ( $C)$ Effect of the CB1 antagonist SR 141716A (1 $\mu \mathrm{M})$ on the vasodilatory response in midafferent arteriolar segments to anandamide $(10 \mu \mathrm{M})$. ${ }^{*}$ Paired responses are different $(P<0.001$, repeated measures ANOVA; $n=9 \mathrm{mAA}$ segments from three kidneys). (D) Comparison of the effects of L-NAME $(0.1 \mathrm{mM})$ and SR $141716 \mathrm{~A}(\mathrm{SR}, 1 \mu \mathrm{M})$ on baseline lumen diameter at $100 \mathrm{mmHg}$ perfusion pressure. *Paired responses within each group are different $(P<0.001$, two-sample $t$ test; $n=9$ mAA segments from three kidneys for each group).

influenced by the level of perfusion pressure $(P<0.003$, twoway repeated measures ANOVA), a factor that directly increases baseline vascular tone through normal autoregulatory adjustments in lumen diameter. Mean $( \pm$ SEM) baseline lumen diameters were $24.9 \pm 2.9(n=7), 18.4 \pm 2.3(n=7)$, and $14.7 \pm 2.8(n=6) \mu \mathrm{m}$ at 60,100 , and $140 \mathrm{mmHg}$, respectively. The $n$ values refer to the number of mAA segments, which were obtained from three kidneys. Significant vasodilation was observed at $1 \mu \mathrm{M}$ anandamide at $140 \mathrm{mmHg}$, and at $10 \mu \mathrm{M}$ at 60 and $100 \mathrm{mmHg}$. As shown, the vasodilation was reversible within $10 \mathrm{~min}$. The highest anandamide concentration used was not sufficient to fully relax the mAA segments, as calciumchannel blockade with $10 \mathrm{mM} \mathrm{MnCl}$ resulted in further dilation at all pressures (by 19.4 $\pm 4.9,77.4 \pm 10.1$, and $143 \pm 19 \%$ of corresponding baseline diameter at 60, 100, and $140 \mathrm{mmHg}$, respectively).

As shown in Fig. $3 \mathrm{~B}$, the vasodilatory response to $10 \mu \mathrm{M}$ anandamide at $100 \mathrm{mmHg}$ perfusion pressure was inhibited by pretreatment for $10 \mathrm{~min}$ with the NO synthase inhibitor L-NAME $(0.1 \mathrm{mM})$, demonstrating that the vasorelaxation was mediated by NO. As shown in Fig. $3 C$, responses to $10 \mu \mathrm{M}$ anandamide at $100 \mathrm{mmHg}$ perfusion pressure were also inhibited by pretreatment for 10 min with $1 \mu \mathrm{M}$ SR 141716A, a specific antagonist for the $\mathrm{CB} 1$ receptor (32).

Fig. $3 D$ shows that SR 141716 A had no effect on mAA lumen diameter at $100 \mathrm{mmHg}$ perfusion pressure. For comparison, the figure also shows the marked vasoconstriction that results in renal arterioles from pretreatment with L-NAME. These observations suggest that anandamide does not exert a significant influence over basal vascular tone in renal afferent arterioles perfused in vitro.

Fig. 4 shows the effects of indomethacin pretreatment (10 $\mu \mathrm{M}$ for $10 \mathrm{~min}$ ) on anandamide-induced vasodilation in renal juxtamedullary arterioles. The top shows four videomicrographs of the same afferent arteriolar segment, the bottom, the mean results from eight arterioles perfused at $100 \mathrm{mmHg}$. Al- though indomethacin resulted in a small but significant constriction of baseline mAA diameter $(8.6 \pm 2.3 \%, P<0.05)$, it had no effect on the vasodilatory response to anandamide (10 $\mu \mathrm{M})(26.0 \pm 3.0$ vs. $23.8 \pm 2.4 \%$ before and after indomethacin $)$.

Anandamide-induced NO production. Anandamide-stimulated NO production was verified with NO-sensitive amperometric electrodes in segments of rat arteries perfused in vitro

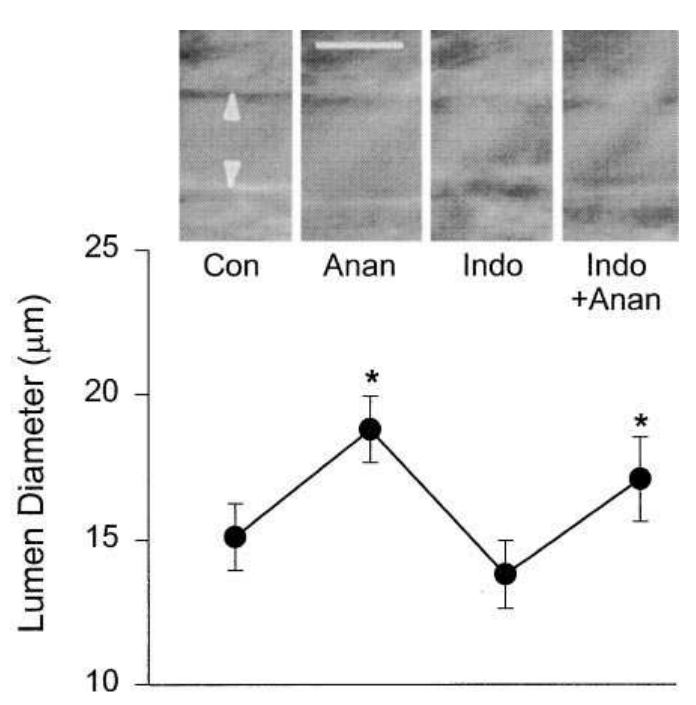

Figure 4. Effect of indomethacin (Indo, $10 \mu \mathrm{M}$ ) on midafferent arteriolar responses to $10 \mu \mathrm{M}$ anandamide (Anan). The top are videomicrographs showing typical responses in a single midafferent arteriole. The arrows show the vessel lumen, and the bar is $25 \mu \mathrm{m}$. The corresponding mean values $\pm \operatorname{SEM}(n=8 \mathrm{mAA}$ segments from three kidneys) are shown below each panel. *Diameter different from corresponding baseline, $P<0.05$, one-way repeated measures ANOVA. Baseline diameter during indomethacin was also significantly less than control; $P<0.05$. 


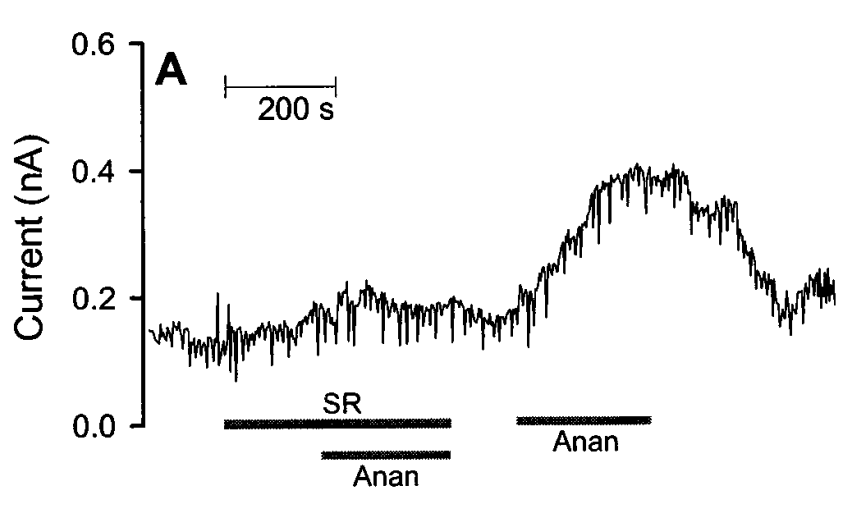

with KRB solution. Anandamide (10 nM) increased NO oxidation current $(\Delta[\mathrm{NO}] \sim 24 \pm 4 \mathrm{nM}, n=7)$. A typical tracing is shown in Fig. 5, which also illustrates inhibition by the CB1 receptor blocker SR 141716A (32). NO release in this preparation was more sensitive to anandamide than were the bloodperfused JM afferent arterioles, where $1 \mu \mathrm{M}$ was needed to elicit significant vasodilation. Anandamide $(1 \mu \mathrm{M})$ also stimulated NO release from cultured renal microvascular endothelial cells $(\Delta[\mathrm{NO}] \sim 14.4 \pm 4.7 \mathrm{nM}, n=4)$. NO release from cultured endothelial cells was inhibited by L-NAME (data not shown).

Inhibition of norepinephrine release by anandamide. As previously demonstrated (28), exposing tissues in vitro to $50 \mathrm{mM}$ $\mathrm{KCl}$ induces a calcium-dependent release of preloaded tritiated monoamines. Fig. 6 shows that $1 \mu \mathrm{M}$ anandamide suppresses $\mathrm{KCl}$-stimulated release of $\left[{ }^{3} \mathrm{H}\right]$ norepinephrine from rat renal arterial segment. This action of anandamide was antagonized by preexposing the tissue to SR 141716A, a CB1 receptor antagonist $(1 \mu \mathrm{M})$. SR $141716 \mathrm{~A}$, when applied alone, does not alter the $\mathrm{KCl}$-stimulated release of $\left[{ }^{3} \mathrm{H}\right] \mathrm{NE}$ within the concentration range of 1-10 $\mu \mathrm{M}$ (data not shown). Furthermore, the NO synthase inhibitor L-NAME also antagonizes the anandamide inhibition of $\left[{ }^{3} \mathrm{H}\right] \mathrm{NE}$ release, demonstrating that anandamide exerts this neurosuppressive effect via NO.

\section{Discussion}

The results of this study demonstrate the presence of an anandamide signaling system within the kidney. In particular, renal endothelial and mesangial cells produce and metabolize anandamide, and both express high-affinity anandamide receptors. As expected, anadamide can only be displaced from specific CB1 binding sites in endothelial cells by known agonists (CP 55940 and WIN 55,212-2) and the antagonist SR 141716A (for review see references 33 and 34). Furthermore, exogenous anandamide causes afferent arteriolar vasodilation and suppresses norepinephrine release from renal sympathetic nerves on renal arcuate artery segments. Exposure of endothelial cells and intact renal arterial segments to exogenous anandamide stimulates the release of NO, which is a major mediator of anandamide's actions on afferent arteriolar resistance and renal noradrenergic release.

Cultured mesangial and endothelial cells contain low levels of anandamide, and exhibit the ability to synthesize ananda-

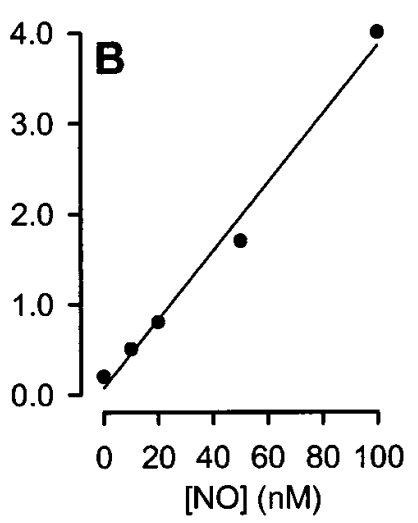

Figure 5. (A) Stimulation of NO production by anandamide in renal arterial segments perfused in vitro. $\mathrm{NO}$ was measured with an NO-sensitive electrode using differential pulse amperometry. Shown is a typical response to luminal application of $10 \mathrm{nM}$ anandamide, and blockade of the response by SR 141716A, a CB1 receptor antagonist. The rise in electrode current elicited by anandamide in this experiment corresponds to a rise in $\mathrm{NO}$ concentration at the electrode of $\sim 20 \mathrm{nM}$.

(B) Typical calibration curve for the NO-sensitive electrode.

mide from arachidonic acid and ethanolamine and to catabolize it by amidase activity. At this time it is not clear whether anandamide is synthesized by the well-established $N$-acylation-phosphodiesterase pathway $(35,36)$ that produces primarily saturated and monounsaturated NAEs via NAPE, or whether it is produced by a separate mechanism. In the central nervous system, the observed condensation of arachidonic acid and ethanolamine in vitro $(17,37,38)$ is unlikely to occur in vivo due to the high $K_{\mathrm{m}}$ values of both substrates. NAE amidohydrolases are known to act in reverse in the presence of high substrate concentrations $(30,31,39)$, which could account

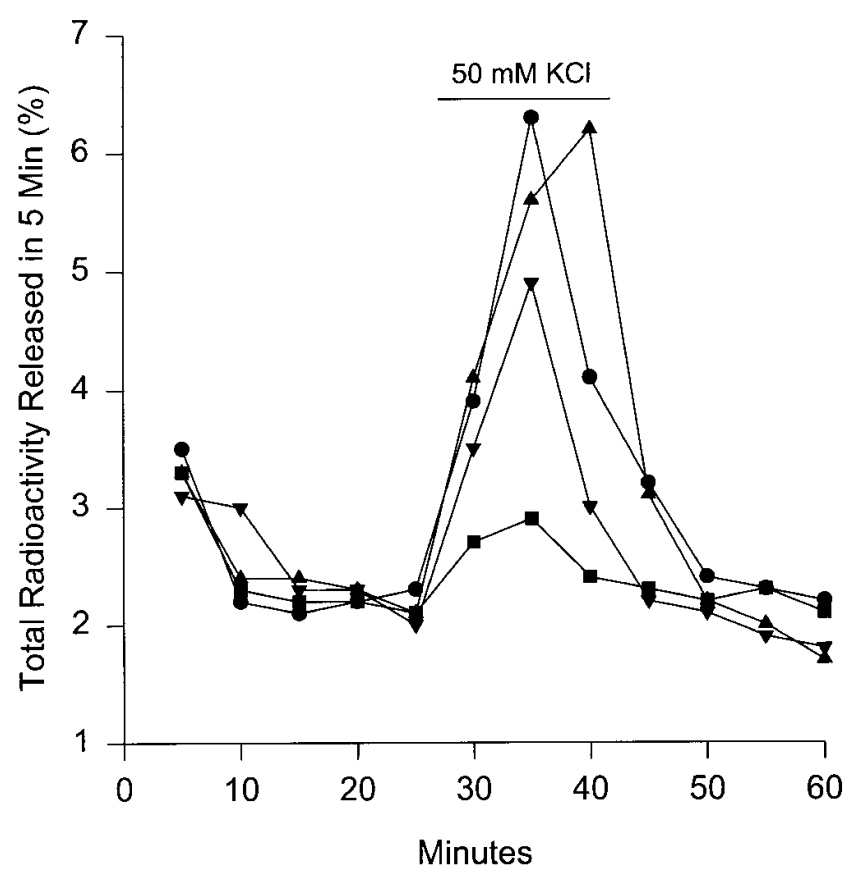

Figure 6. Inhibition by anandamide of $\mathrm{KCl}$-stimulated $\left[{ }^{3} \mathrm{H}\right]$ norepinephrine release from renal sympathetic nerves on freshly dissected rat renal arterial trees. This neuroinhibitory effect of anandamide could be blunted by $1 \mu$ M SR 141716 A, or by $0.1 \mathrm{mM} \mathrm{L-NAME}$. The values shown are the averages of duplicate experiments, each of which analyzed pooled tissue from four kidneys. Circles, control; squares, anandamide $\left(10^{-6} \mathrm{M}\right)$; upward triangles, SR $\left(10^{-6} \mathrm{M}\right)$; downward triangles, anandamide + L-NAME $\left(10^{-4} \mathrm{M}\right)$. 
for the observed biosynthetic activity. Recent work by Sugiura et al. (40) also supports the concept that all NAEs, including anandamide, are produced in brain by the same pathway. Other tissues, however, may possess alternative mechanisms for the selective synthesis of anandamide $(8,41)$.

Renal endothelial cells express mRNA for the cannabinoid type- 1 receptor, and selectively bind anandamide $\left(K_{\mathrm{d}}=\right.$ $27.4 \mathrm{nM})$. Mesangial cells also express messages for both the $\mathrm{CB} 1$ and $\mathrm{CB} 2$ receptors. $\mathrm{CB} 1$ and its isoform $\mathrm{CB} 1 \mathrm{~A}$ are mainly expressed in the central nervous system, and to a lower extent in peripheral tissue such as adrenal gland, heart, lung, prostate, uterus, ovary, testis, bone marrow, thymus, and tonsils. In contrast, the CB2 gene, which is also expressed in cerebellar granular neurons (14), is particularly abundant in immune tissues, with an expression level 10-100-fold higher than that of CB1 (42).

Renal endothelial cells and renal arterial segments in vitro respond to anandamide by increasing NO production, a response that is inhibitable by a specific antagonist of the CB1 receptor. The subsequent vasodilation is consistent with the known systemic depressor actions of $\Delta^{9}$-tetrahydrocannabinol and anandamide in humans and animals $(43,44)$. At present, there is no information about the linkage between CB1 receptor activation and endothelial NO production. In neural cells, cannabinoids have been shown to inhibit adenylate cyclase via pertussis-toxin-sensitive G-protein (10), to inhibit agoniststimulated formation of inositol phosphates (11), and to inhibit $\mathrm{N}$-type calcium channels via a pertussis-toxin-sensitive G-protein mechanism that does not involve cAMP (12). Further study will be required to establish how anandamide activation of CB1 receptors stimulates endothelial NO synthase.

The studies in perfused intact preglomerular juxtamedullary afferent arterioles show that anandamide induces a reversible vasodilation in blood-perfused afferent arterioles at micromolar concentrations, while it can stimulate NO release from renal arterial segments perfused with Krebs-bicarbonateRingers solution at a much lower concentration $(10 \mathrm{nM})$. This difference in sensitivities between these two preparations is likely a consequence of the different modes of drug application (luminal vs. abluminal), albumin binding, and the partitioning of exogenous lipophilic anandamide into erythrocyte and epithelial cell membranes. Nevertheless, the results further demonstrate that anandamide's renal vascular action can be blocked by either a selective CB1 receptor antagonist, or by a NO synthase inhibitor, behavior consistent with our findings of CB1 receptor-mediated NO production in cultured rat microvascular endothelial cells and renal arterial segments in vitro. Although these results indicate that NO plays an important role in anandamide-induced vasorelaxation, they are not sufficient to rule out a direct effect of anandamide on the vascular smooth muscle cells. The reason is that NO synthase inhibition profoundly increases the tone of blood-perfused renal preglomerular vessels ( $\sim 30 \%$ vasoconstriction $)$, and this may have masked additional vasodilatory effects of anandamide. CB1 receptor inhibition had no effect on resting vascular tone, behavior consistent with the low levels of anandamide we found in renal tissues.

Our findings that the renal vascular actions of anandamide are mediated by NO (while they are not influenced by cyclooxygenase inhibition) differs from the results of a recent study in rat cerebral arterioles by Ellis et al. (14). These investigators found that anandamide-induced vasodilation could not be blocked by topical application of L-NAME, but was inhibited by topical application of indomethacin. In the absence of any obvious technical differences, these results suggest the possibility of differences in the mechanism of anandamide action between renal and cerebral arterioles. Renal afferent arterioles are $\sim 50 \%$ smaller than the cerebral arterioles studied, and exhibit lower sensitivity ( $\mathrm{nM}-\mu \mathrm{M}$ range) to anandamide than do the cerebral arteries ( $\mathrm{pM}$ range). Renal arterioles have higher basal NO synthase activity, as evidenced by the $\sim 30 \%$ constriction produced by topical application of L-NAME in afferent arterioles, whereas topical application of the same dose of L-NAME had no effect on cerebral arteriolar diameter (14). These authors also suggest that part of the vasodilatory action of anandamide in the micromolar concentration range in the brain might arise from arachidonic acid released by the metabolism of anandamide. In renal afferent arterioles, however, the combination of the ineffectiveness of indomethacin, together with the complete blockade of anandamide-induced vasodilation by CB1 receptor antagonism, argues against a nonspecific mechanism related to anandamide metabolism. In part, this difference may be related to the lower levels of anandamide amidase in renal tissues in comparison to brain tissues. Finally, the renal vascular actions of anandamide in both cultured cells and intact vessels appear to be initiated fully by CB1 receptor activation. Although the effects of SR 141716A were not evaluated in cerebral arterioles (14), a different receptor or signaling mechanism may be involved, given that the $K_{\mathrm{d}}$ for the CB1 receptor is orders of magnitude greater than the observed picomolar threshold concentration for vasodilation in cerebral arterioles.

CB1 receptor-dependent NO release also appears to be an important mediator of the inhibition by anandamide of $\mathrm{KCl}$ stimulated norepinephrine release from the sympathetic nerves on renal arteries. It is known that anandamide modulates neurotransmitter release $(15,16)$, twitch responses in vas deferens (45), and dopamine release from invertebrate ganglia (G.B. Stefano, personal communication). Our results indicate a linkage between cannabinoid-induced suppression of the renal sympathetic nerves and NO release, a finding consistent with previous findings that NO suppresses NE release in heart and kidney $(46,47)$. Interestingly, opiate alkaloids, which also inhibit catecholamine release, also stimulate NO release $(28,48)$. The neuromodulatory role of NO seems to be especially important in the renal circulation, as the hypertension induced by NO synthase inhibition is ameliorated by renal denervation (49). In addition, our results suggest that the vasodilatory action of anandamide may be amplified in states where renal sympathetic activity is high; behavior consistent with this concept has been observed in the systemic circulation of rats by Lake et al. (43). In this regard, it should be noted that the preparation we used to study perfused afferent arterioles is denervated, a factor that may have limited the magnitude of anandamide's vasorelaxant action.

Some intriguing insight into the potential physiological importance of anandamide in the kidney comes from a recent study by Randall et al. (50), suggesting that anandamide may be an endothelial-derived hyperpolarizing factor that acts by activating potassium channels in vascular smooth muscle. These investigators showed that the NO-independent vasodilation elicited by bradykinin in mesenteric arteries could be completely inhibited by CB1 receptor antagonism by SR 141716A, and that a similar phenomenon could be seen in the 
kidney on the basis of changes in renal vascular resistance in vivo. Although these results need detailed verification in the kidney, they imply that endothelial cells may release anandamide in response to vasoactive agents that stimulate endothelial NO production. Anandamide has also been shown to inhibit propagation of calcium waves by inhibiting gap junctional conductance in striatial astrocytes (13). As gap junctional communication has been shown to be an important factor in the propagation of constrictive responses in preglomerular vessels (51) and of calcium waves between mesangial cells (20), anandamide may also modulate mesangial contraction and the integrated behavior of the renal microcirculation. Although nothing is known at present about the regulation of anandamide synthesis in endothelial cells, these findings suggest that the cannabinoid/anandamide signaling system, which has been retained for over 500 million yr in evolutionary diverse organisms (52-55), may play an important role in the regulation of renal hemodynamics.

\section{Acknowledgments}

The authors thank Frederico Casares, Christos M. Rialas, and Ajia Birzgalis, for assistance with these studies. SR 141716A was kindly provided by the National Institute on Drug Abuse. CP 55940 was a gift from Lawrence Melvin of Pfizer, Inc.

These studies were supported by National Institutes of Health grants DA 06668 (S.K. Dey); MH/DA 17138, DA 09010, National Institutes of Health Fogarty Grant INT 00045 (G.B. Stefano), National Institutes of Health grant DA 09374 (D.G. Deutsch), and National Institutes of Health grant DK 45462 (M.S. Goligorsky).

\section{References}

1. Evans, F.J. 1991. Cannabinoids: the separation of central from peripheral effects on a structural basis. Planta Med. 57(Suppl. 1)60-67.

2. Matsuda, L.A., S.J. Lolait, M.J. Brownstein, A.C. Young, and T.I. Bonner. 1990. Structure of a cannabinoid receptor and functional expression of the cloned cDNA. Nature (Lond.). 346:561-564.

3. Munro, S., K.L. Thomas, and M. Abu-Shaar. 1993. Molecular characterization of a peripheral receptor for cannabinoid. Nature (Lond.). 365:61-65.

4. Devane, W.A., L. Hanus, A. Breuer, R.G. Pertwee, L.A. Stevenson, G. Griffin, D. Gibson, A. Mandelbaum, A. Etinger, and R. Mechoulam. 1992. Isolation and structure of a brain constituent that binds to the cannabinoid receptor. Science (Wash. DC). 258:1946-1949.

5. Schmid, P.C., R.J. Krebsbach, S.R. Perry, T.M. Dettmer, J.L. Maasson, and H.H. Schmid. 1995. Occurrence and postmortem generation of anandamide and other long-chain $N$-acylethanolamines in mammalian brain. FEBS Lett. 375 (Corrigendum 385:125-126, 1996):117-120.

6. Kempe, K., F.F. Hsu, A. Bohrer, and J. Turk. 1996. Isotope dilution mass spectrometric measurements indicate that arachidonylethanolamide, the proposed endogenous ligand of the cannabinoid receptor, accumulates in rat brain tissue post mortem but is contained at low levels in or is absent from fresh tissue. J. Biol. Chem. 271:17287-17295.

7. Felder, C.C., A. Nielsen, E.M. Briley, M. Palkovit, J. Priller, J. Axelrod, D.N. Nguyen, J.M. Richardson, R.M. Riggins, G.A. Koppel, et al. 1996. Isolation and measurement of the endogenous cannabinoid receptor agonist, anandamide, in brain and peripheral tissues of human and rat. FEBS Lett. 393:231235.

8. Schmid, P.C., B.C. Paria, R.J. Krebsbach, H.H.O. Schmid, and S.K. Dey. 1997. Changes in anandamide levels in mouse uterus are associated with uterine receptivity for embryo implantation. Proc. Natl. Acad. Sci. USA. 94:4188-4192.

9. Sugiura, T., S. Kondo, A. Sukagawa, T. Tonegawa, S. Nakane, A. Yamashita, and K. Waku. 1996. Enzymatic synthesis of anandamide, an endogenous cannabinoid receptor ligand, through $\mathrm{N}$-acylphosphatidylethanolamine pathway in testis: involvement of $\mathrm{Ca}^{2+}$-dependent transacylase and phosphodiesterase activities. Biochem. Biophys. Res. Commun. 218:113-117.

10. Howlett, A.C., M. Bidaut-Russell, W.A. Devane, L.S. Melvin, M.R. Johnson, and M. Herkenham. 1990. The cannabinoid receptor: biochemical, anatomical and behavioral characterization. Trends Neurosci. 13:420-423.

11. Nah, S.Y., D. Saya, and Z. Vogel. 1993. Cannabinoids inhibit agoniststimulated formation of inositol phosphates in rat hippocampal cultures. Eur. J. Pharmacol. 246:19-24.
12. Mackie, K., and B. Hille. 1992. Cannabinoids inhibit N-type calcium channels in neuroblastoma-glioma cells. Proc. Natl. Acad. Sci. USA. 89:38253829 .

13. Venance, L., D. Piomelli, J. Glowinski, and C. Giaume. 1995. Inhibition by anandamide of gap junctions and intercellular calcium signalling in striatal astrocytes. Nature (Lond.) 376:590-594.

14. Ellis, E.F., S.F. Moore, and K.A. Willoughby. 1995. Anandamide and delta 9-THC dilation of cerebral arterioles is blocked by indomethacin. Am. J. Physiol. 269:H1859-H1864.

15. Shen, M., T.M. Piser, V.S. Seybold, and S.A. Thayer. 1996. Cannabinoid receptor agonists inhibit glutamatergic synaptic transmission in rat hippocampal cultures. J. Neurosci. 16:4322-4334.

16. Van der Kloot, W. 1994. Anandamide, a naturally-occurring agonist of the cannabinoid receptor, blocks adenylate cyclase at the frog neuromuscular junction. Brain Res. 649:181-184.

17. Deutsch, D.G., and S.A. Chin. 1993. Enzymatic synthesis and degradation of anandamide, a cannabinoid receptor agonist. Biochem. Pharmacol. 46: 791-796.

18. Shire, D., C. Carillon, M. Kaghad, B. Calandra, M. Rinaldi-Carmona, G. Le Fur, D. Caput, and P. Ferrara. 1995. An amino-terminal variant of the central cannabinoid receptor resulting from alternative splicing. J. Biol. Chem. 270: 3726-3731.

19. Folch, J., M. Lees, and G.H. Sloane-Stanley. 1957. A simple method for the isolation and purification of total lipides from animal tissue. J. Biol. Chem. 226:497-507.

20. Iijima, K., L.C. Moore, and M.S. Goligorsky. 1991. Syncytial organization of cultured rat mesangial cells. Am. J. Physiol. 260:F848-F855.

21. Tsukahara, H., D.V. Gordienko, B. Tonshoff, M.C. Gelato, and M.S Goligorsky. 1994. Direct demonstration of insulin-like growth factor-I-induced nitric oxide production by endothelial cells. Kidney Int. 45:598-604.

22. Schmid, P.C., V. Natarajan, B.K. Weis, and H.H. Schmid. 1986. Hydrolysis of N-acylated glycerophospholipids by phospholipases A2 and D: a method of identification and analysis. Chem. Phys. Lipids. 41:195-207.

23. Das, S.K., B.C. Paria, I. Chakraborty, and S.K. Dey. 1995. Cannabinoid ligand-receptor signaling in the mouse uterus. Proc. Natl. Acad. Sci. USA. 92: 4332-4336.

24. Paria, B.C., S.K. Das, G.K. Andrews, and S.K. Dey. 1993. Expression of the epidermal growth factor receptor gene is regulated in mouse blastocysts during delayed implantation. Proc. Natl. Acad. Sci. USA. 90:55-59.

25. Omeir, R.L., S. Chin, Y. Hong, D.G. Ahern, and D.G. Deutsch. 1995. Arachidonoyl ethanolamide-[1,2-14C] as a substrate for anandamide amidase. Life Sci. 56:1999-2005.

26. Casellas, D., and L.G. Navar. 1984. In vitro perfusion of juxtamedullary nephrons in rats. Am. J. Physiol. 246:F349-F358.

27. Casellas, D., and L.C. Moore. 1990. Autoregulation and tubuloglomerular feedback in juxtamedullary glomerular arterioles. Am. J. Physiol. 258:F660F669.

28. Stefano, G.B., B. Hall, M.H. Makman, and B. Dvorkin. 1981. Opioids inhibit potassium-stimulated dopamine release in the marine mussel Mytilus edulis and in the cephalopod, Octopus bimaculatus. Science (Wash. DC). 213: 928-930.

29. Schmid, P.C., P.V. Reddy, V. Natarajan, and H.H.O. Schmid. 1983. Metabolism of $\mathrm{N}$-acylethanolamine phospholipids by a mammalian phosphodiesterase of the phospholipase D type. J. Biol. Chem. 258:9302-9306.

30. Ueda, N., Y. Kurahashi, S. Yamamoto, and T. Tokunaga. 1995. Partial purification and characterization of the porcine brain enzyme hydrolyzing and synthesizing anandamide. J. Biol. Chem. 270:23823-23827.

31. Schmid, P.C., M.L. Zuzarte-Augustin, and H.H. Schmid. 1985. Properties of rat liver N-acylethanolamine amidohydrolase. J. Biol. Chem. 260:1414514149.

32. Rinaldi-Carmona, M., F. Barth, M. Heaulme, D. Shire, B. Calandra, C. Congy, S. Martinez, J. Maruani, G. Neliat, D. Caput, et al. 1994. SR141716A, a potent and selective antagonist of the brain cannabinoid receptor. FEBS Lett. 350:240-244.

33. Mechoulam, R., L. Hanus, and B.R. Martin. 1994. Search for endogenous ligands of the cannabinoid receptor. Biochem. Pharmacol. 48:1537-1544.

34. Di Marzo, V., L. De Petrocellis, T. Bisogno, and S. Maurelli. 1995. Pharmacology and physiology of the endogenous cannabimimetic mediator anandamide. J. Drug Dev. Clin. Pract. 7:199-219.

35. Schmid, H.H., P.C. Schmid, and V. Natarajan. 1990. N-acylated glycerophospholipids and their derivatives. Prog. Lipid Res. 29:1-43.

36. Schmid, H.H., P.C. Schmid, and V. Natarajan. 1996. The N-acylationphosphodiesterase pathway and cell signaling. Chem. Phys. Lipids. 80:133-142.

37. Kruszka, K.K., and R.W. Gross. 1994. The ATP- and CoA-independent synthesis of arachidonoylethanolamide. A novel mechanism underlying the synthesis of the endogenous ligand of the cannabinoid receptor. J. Biol. Chem. 269:14345-14348.

38. Devane, W.A., and J. Axelrod. 1994. Enzymatic synthesis of anandamide, an endogenous ligand for the cannabinoid receptor, by brain membranes. Proc. Natl. Acad. Sci. USA. 91:6698-6701.

39. Desarnaud, F., H. Cadas, and D. Piomelli. 1995. Anandamide amidohydrolase activity in rat brain microsomes. Identification and partial characteriza- 
tion. J. Biol. Chem. 270:6030-6035.

40. Sugiura, T., S. Kondo, A. Sukagawa, S. Nakane, A. Yamashita, Y. Ishima, and K. Waku. 1996. Transacylase-mediated and phosphodiesterase-mediated synthesis of $\mathrm{N}$-arachidonoylethanolamine, and endogenous cannabinoidreceptor ligand, in rat brain microsomes. Comparison with synthesis from free arachidonic acid and ethanolamine. Eur. J. Biochem. 240:43-62.

41. Paria, B.C., D.G. Deutsch, and S.K. Dey. 1996. The uterus is a potential site for anandamide synthesis and hydrolysis: differential profiles of anandamide synthase and hydrolase activities in the mouse uterus during the preimplantation period. Mol. Reprod. Dev. 45:183-192.

42. Galiegue, S., S. Mary, J. Marchand, D. Dussossoy, D. Carriere, P. Carayon, M. Bouaboula, D. Shire, G. Le Fur, and P. Casellas. 1995. Expression of central and peripheral cannabinoid receptors in human immune tissues and leukocyte subpopulations. Eur. J. Biochem. 232:54-61.

43. Lake, K.D., B.R. Martin, G. Kunos, and K. Varga. 1997. Cardiovascular effects of anandamide in anesthetized and conscious normotensive and hypertensive rats. Hypertension (Dallas). 29:1204-1210.

44. Graham, J.P.D. 1986. The cardiovascular actions of cannabinoids. In Cannabinoids as Therapeutic Agents. R. Mechoulam, editor. CRC Press Inc., Boca Raton, FL.

45. Pertwee, R.G., S.R. Fernando, G. Griffin, V. Abadji, and A. Makriyannis. 1995. Effect of phenylmethylsulphonyl fluoride on the potency of anandamide as an inhibitor of electrically evoked contractions in two isolated tissue preparations. Eur. J. Pharmacol. 272:73-78.

46. Schwarz, P., R. Diem, N.J. Dun, and U. Forstermann. 1995. Endogenous and exogenous nitric oxide inhibits norepinephrine release from rat heart sympathetic nerves. Circ. Res. 77:841-848.

47. Egi, Y., Y. Matsumura, S. Murata, T. Umekawa, K. Hisaki, M. Takaoka, and S. Morimoto. 1994. The effects of NG-nitro-L-arginine, a nitric oxide synthase inhibitor, on norepinephrine overflow and antidiuresis induced by stimulation of renal nerves in anesthetized dogs. J. Pharmacol. Exp. Therap. 269:529-
535

48. Stefano, G.B., B. Scharrer, E.M. Smith, T.K. Hughes, H.I. Magazine, T.V. Bilfinger, A.R. Hartman, G.L. Fricchione, Y. Liu, and M.H. Makman. 1996. Opioid and opiate immunoregulatory processes. Crit. Rev. Immunol. 16: 109-144.

49. Matsuoka, H., H. Nishida, G. Nomura, B.N. Van Vliet, and H. Toshima 1994. Hypertension induced by nitric oxide synthesis inhibition is renal nerve dependent. Hypertension (Dallas). 23:971-975.

50. Randall, M.D., S.P.H. Alexander, T. Bennett, E.A. Boyd, J.R. Fry, S.M. Gardiner, P.A. Kemp, A.I. McCulloch, and D.A. Kendall. 1996. An endogenous cannabinoid as endothelium-derived vasorelaxant. Biochem. Biophys. Res. Comm. 229:114-120.

51. Wagner, A.J., N.-H. Holstein-Rathlou, and D.J. Marsh. 1997. Internephron coupling by conducted vasomotor responses in normotensive and spontaneously hypertensive rats. Am. J. Physiol. 272 (Renal Physiol. 41):F372F379.

52. Chang, M.C., D. Berkery, R. Schuel, S.G. Laychock, A.M. Zimmerman, S. Zimmerman, and H. Schuel. 1993. Evidence for a cannabinoid receptor in sea urchin sperm and its role in blockade of the acrosome reaction. Mol. Reprod. Dev. 36:507-516.

53. Schuel, H., E. Goldstein, R. Mechoulam, A.M. Zimmerman, and S. Zimmerman. 1994. Anandamide (arachidonylethanolamide), a brain cannabinoid receptor agonist, reduces sperm fertilizing capacity in sea urchins by inhibiting the acrosome reaction. Proc. Natl. Acad. Sci. USA. 91:7678-7682.

54. Stefano, G.B., B. Salzet, and M. Salzet. 1997. Identification and characterization of the leech CNS cannabinoid receptor: coupling to nitric oxide release. Brain Res. In press.

55. Stefano, G.B., Y. Liu, and M.S. Goligorsky. 1996. Cannabinoid receptors are coupled to nitric oxide release in invertebrate immunocytes, microglia, and human monocytes. J. Biol. Chem. 271:19238-19242. 